\title{
Drought Impact on Leaf Phenology and Spring Frost Susceptibility in a Quercus robur L. Provenance Trial
}

\author{
Ivica Čehulić ${ }^{1}$, Krunoslav Sever ${ }^{2}$, Ida Katičić Bogdan ${ }^{2}$, Anamarija Jazbec ${ }^{2}$, Željko Škvorc ${ }^{2}$ (D) \\ and Saša Bogdan 2,*iD \\ 1 Croatian Forest Research Institute, 10450 Jastrebarsko, Croatia; ivicac@sumins.hr \\ 2 Faculty of Forestry; University of Zagreb, 10000 Zagreb, Croatia; ksever@sumfak.hr (K.S.); \\ ikaticic@sumfak.hr (I.K.B.); ajazbec@sumfak.hr (A.J.); zskvorc@sumfak.hr (Ž.Š.) \\ * Correspondence: sbogdan@sumfak.hr
}

Received: 20 November 2018; Accepted: 8 January 2019; Published: 11 January 2019

check for updates

\begin{abstract}
Research highlights: The susceptibility of oaks to late spring and early autumn frosts is directly related to their leaf phenology. Drought may alter the leaf phenology and therefore frost tolerance of oaks. However, the effects of drought on oak leaf phenology and frost resistance have not been thoroughly studied. Background and objectives: One of the consequences of climate change is an increase in the frequency of dry episodes during the vegetation period. Pedunculate oak (Quercus robur $\mathrm{L}$.) is an economically and ecologically important forest tree species that prefers humid habitats. Therefore, knowledge of the impact of drought on this species is of great importance for the adaptation of forestry strategies and practices to altered environmental conditions. The aim of this study was to determine the impact of drought on leaf phenology and spring frost susceptibility in nine provenances. Materials and methods: One-year-old saplings originating from nine European provenances were used in the trial. The saplings were exposed to experimental drought and then re-watered in two subsequent years. Spring and autumn leaf phenology were scored. The trial was impacted by a late spring frost in the third year, and the resulting leaf frost injury was scored. The effects of drought treatment on the phenology and frost susceptibility of plants from the provenances were analysed. Results: Leaf phenology of plants from most of the studied provenances was significantly influenced by the drought treatment $(p<0.001)$. Drought induced a carry-over effect on flushing phenology, which was observed as delayed bud burst (from 0.6 to 2.4 days) in the second year and as advanced bud burst (from 0.1 to 6.3 days) in the third year. Therefore, opposite shifts in flushing phenology may be induced as a result of differences in the time span when plants sense water deficits. In contrast to flushing, autumn leaf phenology was unambiguously delayed following the drought treatments for all studied provenances (from 2.1 to 25.8 days). Differences in late frost susceptibility were predominantly caused by among-provenance differences in flushing phenology. However, the drought treatment significantly increased frost susceptibility in the plants (the rate of frost-injured plants per provenance increased from 3\% to $78 \%$ ). This higher susceptibility to spring frost was most likely caused by the advanced flushing phenology that resulted from the drought treatment in the previous year.
\end{abstract}

Keywords: pedunculate oak; drought; stress; memory; flushing; autumn leaf senescence; phenological shift; carry-over effect

\section{Introduction}

The hazards associated with climate change, including rising temperatures, decreasing precipitation, and an increasing frequency of extreme climatic events, are expected to intensify [1-3]. In general, the productivity of forest ecosystems is severely impaired by water availability, and drought 
may induce episodes of large-scale tree decline in temperate forests [4]. Most likely, such declines will substantially increase the necessity for artificial regeneration of temperate forests. However, the increasing severity and frequency of droughts may also impact forest regeneration, causing unacceptably high seedling mortality rates. Late spring frost is an additional abiotic factor that strongly limits forest regeneration [5]. Therefore, it is necessary to enhance our understanding of the mutual impacts of drought and frost on forest reproductive material.

Pedunculate oak (Quercus robur L.) is a widespread European temperate forest tree species that generally prefers fertile and moist habitats [6], although it is also tolerant to arid habitats such as the forest-steppe ecosystems in eastern Europe (e.g., see [7]). Moreover, this species is one of the most economically valuable European hardwood tree species and is a climax species in forests that harbor high biodiversity. Because the species is mainly adapted to moist habitats, its drought tolerance will become increasingly important for its survival, especially in the presence of additional stresses such as frost, competition, pests, and diseases. Theoretically, pedunculate oak may adapt to stressful environmental changes at the individual, population, and plant community levels [2] through phenotypic modifications (i.e., plasticity), natural selection, and hybridization with related xerophilous species, such as sessile oak and pubescent oak $[8,9]$. In general, oaks are relatively tolerant to drought [10], as they have a xeromorphic leaf structure and root structure that can cope with variability in soil water availability; additionally, oaks display the ability to rapidly resume assimilation after periods of water deficiency [11-15]. However, intraspecific variation in responses to drought occurs among oaks from different provenances. Some of this variation has been attributed to adaptability driven by natural selection in the original provenance habitats $[16,17]$, but in other cases, the original site-level climate of provenances has not been correlated with the responses of oaks to drought (e.g., [18]). Reduced above-ground biomass production, together with a shift towards root growth, is a drought response often observed in oak species [18-20]. Other drought responses by oak include changes in the morphological (e.g., reduced leaf area and chlorophyll content) and physiological (e.g., reduced stomatal conductance and water use efficiency) properties of leaves [21]. Although pedunculate oak does not appear to possess efficient responses to leaf frost injury [22], oak populations display adaptation to frost events in the form of differences in leaf phenology [23]. Additionally, occasional frost events (together with other factors) may have led to high within-population genetic variation in pedunculate oak populations, which are often characterized by various phenological types [24]. For deciduous tree species such as $Q$. robur, the timing of bud burst in spring and leaf senescence in autumn is very important in defining the period of carbon fixation and growth during the vegetation season as well as determining survival due to the increased frequency of climatic extremes such as frosts. Among the most important adaptive traits, phenology is thought to be one of the most affected by climate change [25]. However, it is necessary to further enhance our understanding of the impacts of interactive stressful climatic events on the phenology of deciduous forest tree species. The effects of drought on oak phenology (especially that of the pedunculate oak) have not been thoroughly studied and have been mainly described as earlier growth cessation under dry conditions $[17,26]$, which is also visible as earlier radial growth cessation [27]. Interestingly, drought may induce an after-effect (i.e., a carry-over effect) in the subsequent spring that is indicated by advanced bud burst $[26,28]$. The same effect of water stress on leaf phenology was also recorded in beech [29]. In one report, sessile oak from different provenances showed a drought-induced carry-over effect in the subsequent spring, which was observable as a delay in the bud burst date [30]. To the best of our knowledge, this discrepancy in observed leaf phenological shifts induced by drought in oaks has not been explained, nor reported for other forest tree species. Here, we propose that bud burst shifts that occur as a carry-over effect induced by drought have opposite directions depending on the time span over which the plants sensed the water deficit. That is, if plants sensed the water deficit early in the vegetation period (i.e., in spring), then flushing would likely be delayed in the subsequent year; in contrast, if drought were sensed late (i.e., in summer), then advanced flushing would likely occur in the subsequent year. The effects of drought on oak frost resistance have been 
even less thoroughly studied. In general, few papers address between-provenance genetic variation in oak frost susceptibility (e.g., pedunculate oak [17] and holm oak [31]). One study examined the effect of drought on oak frost hardiness (measured as resistance to winter freezing periods) [32], but it did not evaluate frosts that occurred in late spring or early autumn. As drought may alter phenology and therefore the susceptibility of forest tree species to late spring and early autumn frosts, it is necessary to improve our understanding of these interactive effects.

We established a short-term pedunculate oak provenance trial with seedlings originating from nine provenances along the eastern European north-south gradient, i.e., from Estonia to Italy. Plants from these provenances were experimentally treated to induce drought conditions during two growing seasons. As the trial was affected by a late spring frost in the third year, we had the opportunity to examine variation in oak frost susceptibility among provenances as well as the impact of drought on the frost susceptibility of these plants. The aims of the study were to determine the following: (1) the impact of drought on the flushing phenology of plants from various provenances; (2) the impact of drought on the autumn leaf senescence of plants from these provenances; and (3) among-provenance differences in the impact of drought on spring frost susceptibility.

\section{Materials and Methods}

\subsection{Plant Origin and Trial Design}

In autumn 2013, acorns were collected below crowns of at least ten randomly chosen mature trees in each of nine allegedly natural pedunculate oak stands. The provenances are located along a latitudinal gradient from Estonia to Italy (Table 1). Acorns were sent to the Croatian Forest Research Institute and sown in 0.5-litre polyvinyl chloride (PVC) pots filled with nursery substrate. In spring 2014, germinated seedlings were individually transplanted into 50-litre PVC pots filled with natural soil extracted from a local pedunculate oak forest (soil type: gleysol; $\mathrm{pH}=7.6$; soil texture: silty loam). The soil was homogenized and cleared of stones, leaves, sprouts, and twigs prior to filling the pots. The pots were kept outdoors during the first vegetation period; thus, they were exposed to natural local weather conditions at the nursery of the Croatian Forest Research Institute $\left(45^{\circ} 40^{\prime} 08.27^{\prime \prime} \mathrm{N}\right.$; $15^{\circ} 38^{\prime} 31.96^{\prime \prime} \mathrm{E} ; 141 \mathrm{~m}$ a.s.l.). In spring 2015, the pots were transferred to a greenhouse and arranged following a strip-plot experimental design. The first factor (water availability) had two levels: a control plot and a drought treatment plot (DT plot). The second factor (replication) had three levels. Each provenance was represented within each combination of the factors by various numbers of randomly placed plants (3-9 per provenance due to differences in acorn germination and seedling survival).

Table 1. Location and climatic characterization of the provenance sites.

\begin{tabular}{ccccccc}
\hline Country & $\begin{array}{c}\text { Provenance } \\
\text { Abbreviation }\end{array}$ & Latitude N & Longitude E & T ( ${ }^{\circ}$ C) & PR (mm) & bFFP \\
\hline Estonia & ES & 58.238520 & 22.442890 & 6.1 & 568.3 & April 24th \\
Lithuania & LI & 54.537975 & 23.811175 & 6.4 & 625.3 & April 20th \\
Poland & PL & 51.190300 & 16.549010 & 8.6 & 554.7 & April 11th \\
Hungary & HU & 47.025120 & 18.263499 & 10.8 & 562.0 & April 1st \\
Croatia (Repaš) & CR (RE) & 46.139763 & 17.091610 & 10.8 & 793.2 & April 4th \\
Croatia (Koška) & CR (KO) & 45.569734 & 18.235555 & 10.9 & 719.0 & April 3th \\
Croatia (Karlovac) & CR (KA) & 45.494896 & 15.708384 & 11.4 & 994.7 & March 29th \\
Croatia (Otok) & CR (OT) & 45.094245 & 18.821524 & 11.3 & 745.3 & April 3th \\
Italy & IT & 42.755380 & 11.918041 & 14.3 & 722.8 & February 18th \\
\hline
\end{tabular}

Mean annual temperature (T), mean annual precipitation (PR) and average beginning of the frost-free period in spring (bFFP) were generated with ClimateEU software (version 4.63) (http:/ / www.ualberta.ca/ \{\}ahamann/data/ climateeu.html) for the period of 1901 to 2009. The provenance abbreviations indicate their country of origin.

The trial included a drop-in irrigation system that allowed water availability in the main plots (i.e., control and DT plots) to be controlled. Plants in the control plot were constantly maintained in soil with a high volumetric soil moisture (VSM) content (i.e., 40\%-50\% VSM) during the growing period. 
The VSM content was monitored by soil moisture sensors, which were set up in six representative pots (one in each combination of the factors) and connected to automatic meteorological stations.

\subsection{Treatments}

In the first growing period, the trial was established in a greenhouse that was automatically ventilated, thus preventing excessive heat and air humidity during the summer. Plants in the DT plot were deprived of water on March 30th, 2015 (Figure 1). The drought treatment was stopped, and the plants were re-watered on July 21st (Figure 1), a date when approximately $20 \%$ of the plants in the plot had visible leaf injury symptoms. All plants in the trial continued to regularly receive water until the end of the growing season. During the dormant period of the year (i.e., beginning on November 1st, 2015), the pots were transferred outside the greenhouse and exposed to normal local winter conditions. Because the plants had unexpectedly shown vigorous growth in the greenhouse and threatened to reach the ceiling, the trial was performed outside for the remainder of the study. To prevent the soil from receiving natural precipitation, each pot was covered with polystyrene panels that were shaped to fit around the plant stem and additionally sealed with polyurethane foam and duct tape.

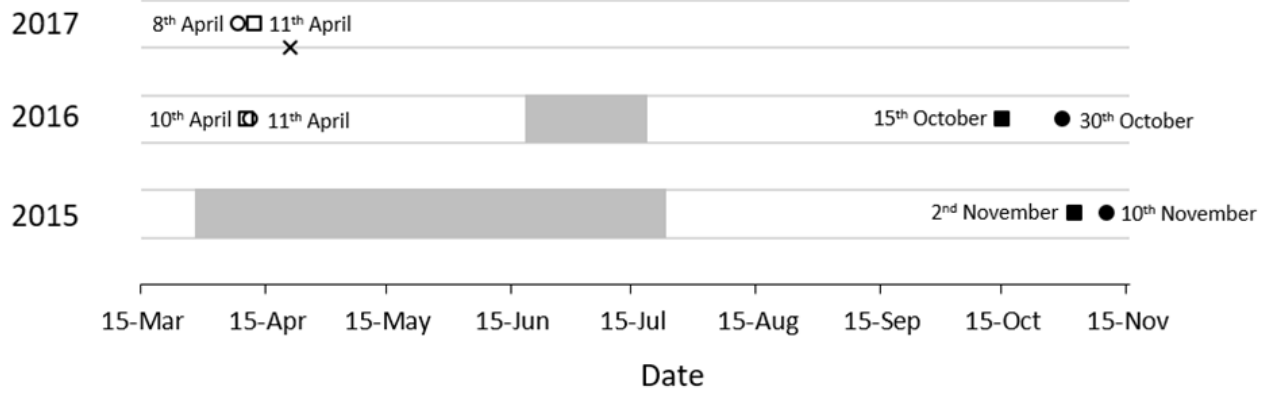

Figure 1. The beginning and end of growing seasons in the control and drought treatment (DT) plots in three consecutive years $(2015,2016$ and 2017). Open symbols indicate the mean bud burst date in the control (square) and DT (circle) plots, whilst closed symbols indicate the mean date of autumn leaf senescence in the control (square) and drought treatment (circle). The symbol $\times$ indicates the late frost event (on 21st April 2017). Grey polygons indicate the duration of drought treatments in 2015 (from 30th March to 21st July) and 2016 (from 20th June to 16th July).

In the subsequent growing period (in 2016), the plants in the DT plot were deprived of water beginning on June 20th. The drought treatment was stopped on July 16th (Figure 1), when almost 25\% of the plants showed visible leaf injury symptoms. Afterwards, the plants in the DT plot continued to receive regular watering until the end of the growing season, similar to the way plants in the control plot were treated.

\subsection{Leaf Phenology Scoring}

Leaf flushing and autumn leaf senescence were studied from 2015 to 2017 (flushing only in the last year).

Leaf flushing phenological phases were scored on all plants in the trial on a 1-8 ordinal scale:

1-bud scales completely closed; buds smaller, darker and hard;

2-buds swelling, scales slightly spaced;

3-bud burst; buds opening, scales considerably more widely spaced, green leaf tips visible;

4-folded leaf visible;

5-leaf unfolding but not yet flattened, small;

6-leaves still relatively small but with flattened blades, blade edges bent downwards, withered, lighter green or reddish; 
7-leaves appear developed, larger but still more tenderly structured (thinner) than fully developed leaves and lighter green or reddish;

8 -leaves fully developed, darker green, thicker.

Autumn leaf phenological phases were scored on a $0-5$ ordinal scale:

0 -leaves completely green with no visible yellowing;

1 -up to $25 \%$ of plant leaves brown;

2 -up to $50 \%$ of plant leaves brown;

3 -more than $50 \%$ of plant leaves brown;

4 -more than $75 \%$ of plant leaves brown;

5-leaves shed.

The day of the year when each plant reached flushing phase 3 was recorded as the bud burst date, and the day of the year when each plant reached autumn leaf phenological phase 3 was recorded as the autumn senescence date. These individual plant data were used for subsequent statistical analyses.

\subsection{Spring Frost Injury Scoring}

A late spring frost affected the trial (as well as a much wider geographic area) on April 21st, 2017. After a warm period (the mean air temperature from April 1st to April 20th was $12{ }^{\circ} \mathrm{C}$, with a maximum temperature of $29.5^{\circ} \mathrm{C}$ ), the air temperature suddenly dropped from the maximum of $13.6^{\circ} \mathrm{C}$ at 3 p.m. on April 20 th to $-0.1^{\circ} \mathrm{C}$ at 8 p.m. on the same day, and the temperature continued to decrease until it reached a minimum of $-5.8^{\circ} \mathrm{C}$ at 5 a.m. on April 21st, after which the temperature rose to $-0.3^{\circ} \mathrm{C}$ by 7 a.m. and continued to rise.

Several days later, there were visible leaf injuries on the plants in the trial. Leaf injuries appeared as necrotic leaf tissue visible as various shades of brown stretching from the margins of the leaf blade towards the midrib. On some leaves, these injuries were located closer to the apex, but on others, the injuries were located closer to the base. In general, there were no cases in which the whole leaf blade surface was necrotic. Additionally, in all cases, a rather low percentage of plant leaves were injured (on average, $5 \%$ of all plant leaves were partly injured). As a result, it was difficult to grade the plants based on frost injury; thus, we decided to record frost damage using a binary scale $(0-$ plant has no visible injuries, and 1 -plant has visible injuries).

\subsection{Statistical Analyses}

Individual plant data on bud burst date and autumn leaf senescence date were used for statistical analyses. All statistical analyses were performed in SAS/STAT 15.1 software, a free version of SAS University Edition by SAS Institute Inc., Cary, NC, USA. Descriptive statistics were performed using the MEANS procedure. Analyses of variance (ANOVAs) were performed using the MIXED procedure to determine the statistical significance of the factors (irrigation treatments, blocks, provenances, and the provenance by treatment interaction) according to the following linear model:

$$
\mathrm{y}_{\mathrm{iklj}}=\mu+\mathrm{T}_{\mathrm{i}}+\mathrm{B}_{\mathrm{j}}+\mathrm{P}_{\mathrm{k}}+\mathrm{TP}_{\mathrm{ik}}+\varepsilon_{\mathrm{ijk}} \text { (ANOVA model) }
$$

where $y_{i j k l}$-individual value of a trait; $\mu$-overall mean; $\mathrm{T}_{\mathrm{i}}$-fixed effect of treatment $\mathrm{i}$, where $\mathrm{i}=1,2$; $B_{j}$-random effect of block $j$, where $j=1,2,3 ; P_{k}$-fixed effect of population $k$, where $k=1,2, \ldots, 9$; $\mathrm{TP}_{\mathrm{ik}}$ - population by treatment interaction; and $\varepsilon_{\mathrm{ijkl}}$-random error.

Assumptions of residual normality and variance homogeneity were tested by using the Shapiro-Wilk test and Levine's test [33] with the GLM and UNIVARIATE procedures in SAS. Residuals were plotted as a function of fitted values to test for variance homogeneity, and the distribution of residuals was also tested. The significance of the irrigation treatments was tested by the Wald test and with the Satterthwaite approximation [34]. Student's $t$-test was performed to establish the significance of differences in the bud burst date between the different groups of frost-injured and uninjured plants. 


\section{Results}

\subsection{Flushing Phenology}

As expected, in spring 2015 (prior to drought treatment), there were no statistically significant differences in the timing of bud burst between the control plot and the DT plot $(\mathrm{F}=2.52 ; p=0.1131)$. However, in spring 2016 (the year after the first drought treatment), the mean bud burst date of plants from almost all (except CR (OT)) provenances in the DT plot was delayed (1.5 days on average), ranging from 0.6 to 2.4 days per provenance (Figure 2). The drought treatment effect was statistically significant $(\mathrm{F}=12.90 ; p=0.0004)$. In spring 2017, the mean bud burst date of plants in the DT plot was advanced by 3 days on average (compared with the control), ranging from 0.1 to 6.3 days per provenance (Figure 2). The only exception was provenance ES, for which plants exhibited a delay in mean bud burst of 1.3 days (Figure 2). The effect of drought on the bud burst date was again highly statistically significant $(\mathrm{F}=31.44 ; p<0.0001)$.

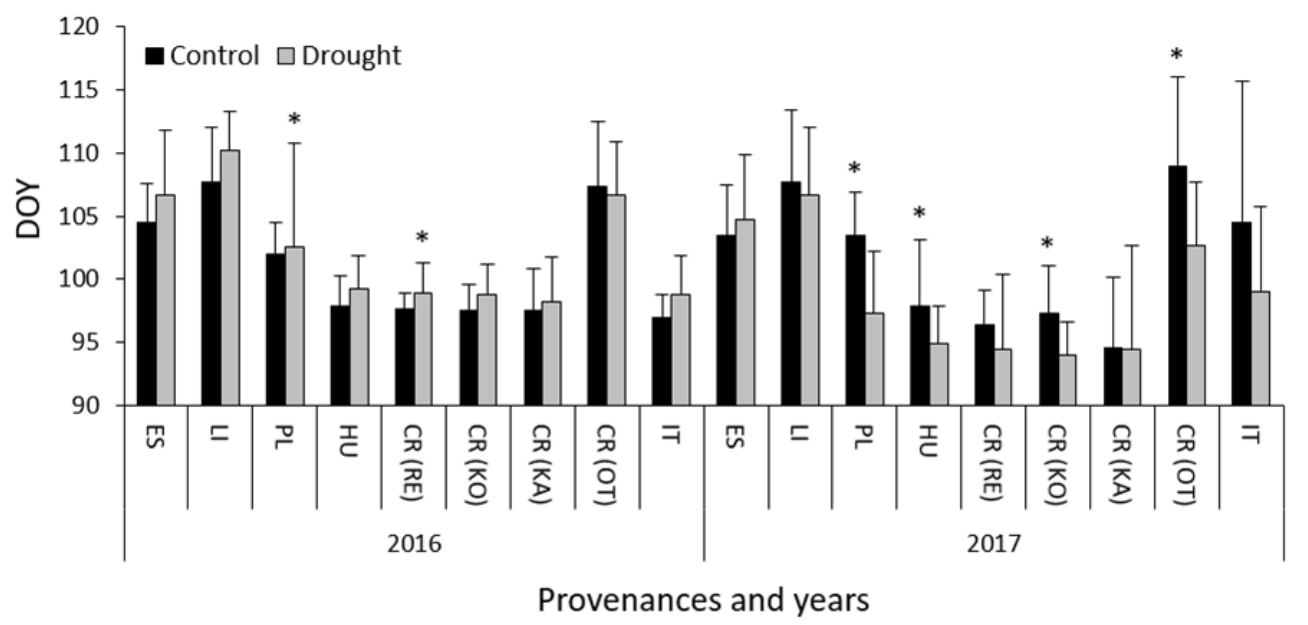

Figure 2. Provenance mean bud burst dates in the treatments (control and drought), expressed as day of year (DOY) in 2016 and 2017. Vertical bars indicate the standard deviation of the mean values. Asterisks above bars indicate significant differences between treatments for the same provenance. Provanance abbreviations: ES-Estonia; LI-Lithuania; PL—Poland; HU—Hungary; CR (RE)—Croatia (Repaš); CR (KO)—Croatia (Koška); CR (KA)—Croatia (Karlovac); CR (OT)—Croatia (Otok); IT_Italy.

\subsection{Autumn Leaf Phenology}

Autumn leaf phenology was scored in 2015 and 2016 after one and two years of successive drought treatments were imposed on plants in the DT plot, respectively. In 2015, the plants exhibited an average delay in senescence of 8 days (ranging from 2 (provenance ES) to 13 (provenance PL) days) (Figure 3). In 2016, leaf senescence was again delayed, in this case by an average of 15 days (ranging from 3 (LI) to 26 (CR (RE) days) (Figure 3). Based on ANOVA, the leaf senescence date of plants in the DT plot was significantly delayed compared to that in the control in both years $(\mathrm{F}=179.00$ and 318.85; $p<0.0001$, respectively). Based on Tukey's test, the mean autumn senescence of plants from only the most northern provenances (ES and LI) did not significantly differ between the DT plot and the control plot. 


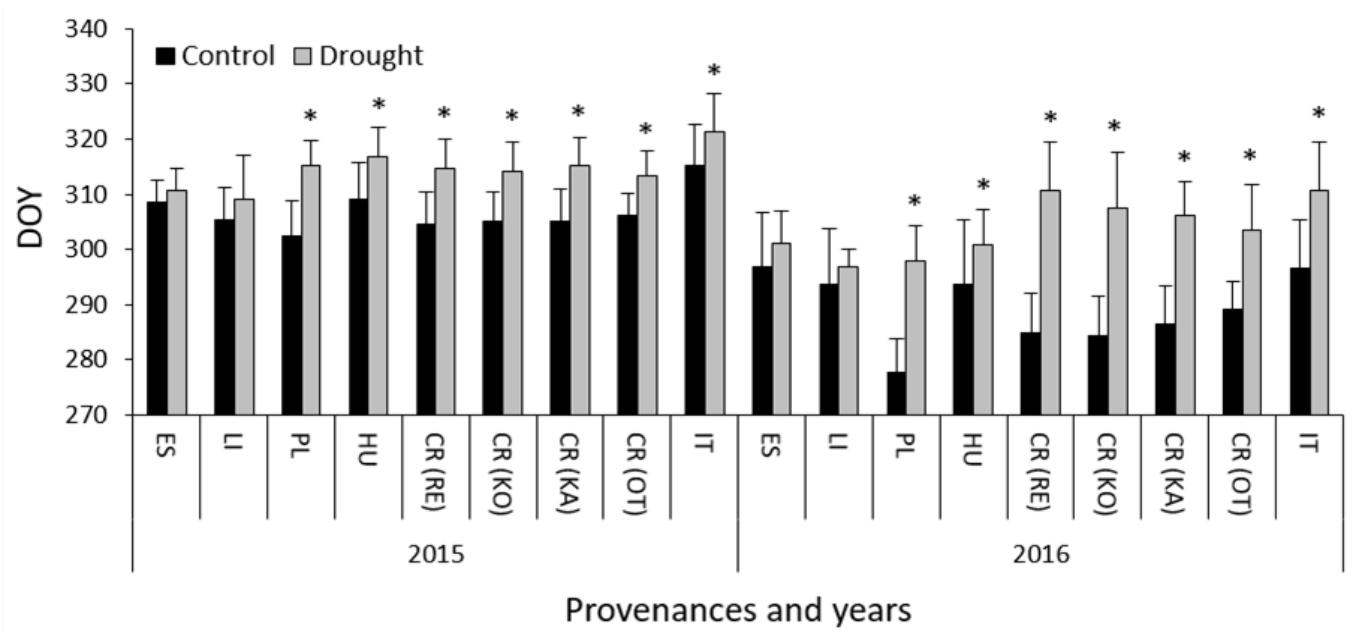

Figure 3. Provenance means of autumn leaf senescence in the treatments (control and drought) expressed as day of year (DOY) in 2015 and 2016. Vertical bars indicate the standard deviation of the mean values. Asterisks above bars indicate significant differences between treatments for the same provenance. Provanance abbreviations: ES-Estonia; LI-Lithuania; PL—Poland; HU—Hungary; CR (RE)—Croatia (Repaš); CR (KO)—Croatia (Koška); CR (KA)—Croatia (Karlovac); CR (OT)—Croatia (Otok); IT-Italy.

\subsection{Spring Frost Susceptibility}

The trial was impacted by a late spring frost occurring on April 21st, 2017. The proportion of frost-injured plants varied among provenances. More than $90 \%$ of plants from provenances CR (KO), $\mathrm{HU}$, and CR (RE) were injured in the DT plot, though no plants from provenance LI were injured (Figure 4). Additionally, a larger proportion of damaged plants were observed in the DT plots for most provenances, indicating an adverse impact of drought on frost tolerance.

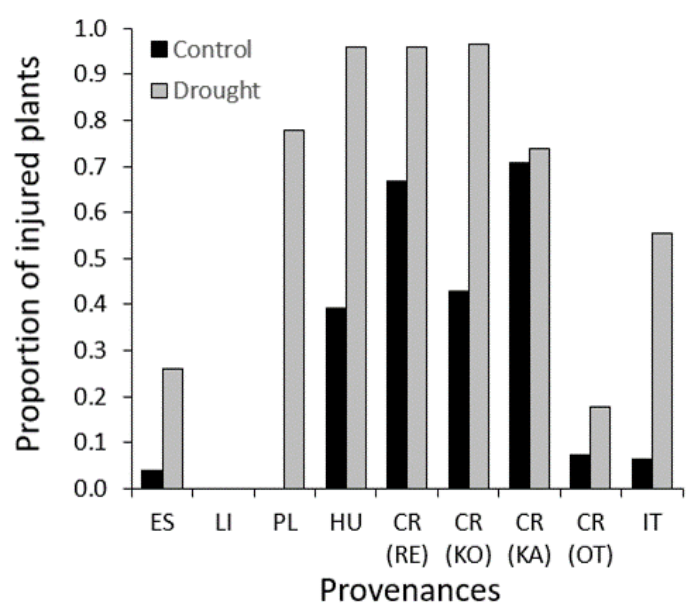

Figure 4. Proportions of frost-injured plants by provenance and treatment. Provanance abbreviations: ES-Estonia; LI_Lithuania; PL_Poland; HU—Hungary; CR (RE)—Croatia (Repaš); CR (KO)—Croatia (Koška); CR (KA)—Croatia (Karlovac); CR (OT)—Croatia (Otok); IT_Italy.

Based on the relationship between the state of flushing on April 21st and the incidence of frost injuries, plants that had entered flushing phases 5, 6, and 7 were injured (Figure 5). All plants that had entered flushing phase 7 were injured in both the control and DT plots (only a single plant in the DT plot had no visible symptoms of frost injury). Additionally, all plants in the DT plot that had entered flushing phase 6 were injured, whereas only $44 \%$ of plants in the same flushing phase had visible leaf 
injuries in the control plot. There was an obvious difference in the proportion of injured plants that had reached flushing phase 5 between the control and DT plots (Figure 5).

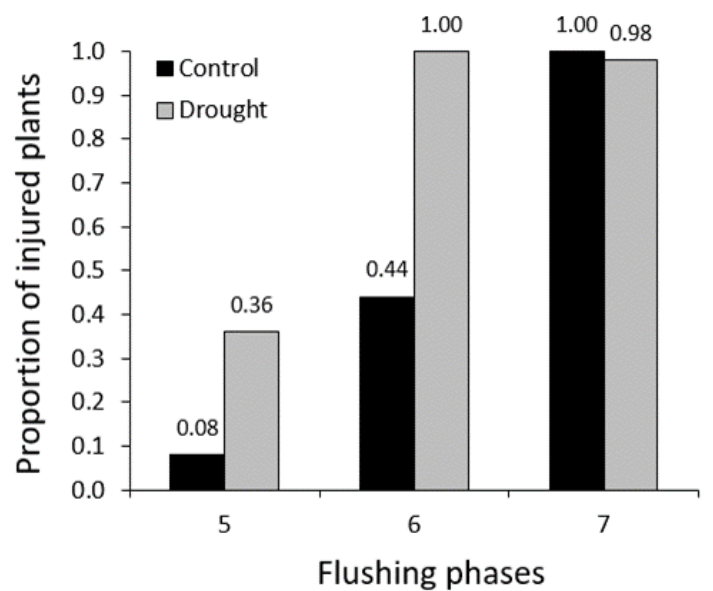

Figure 5. Total proportion of frost-injured plants from all provenances (in the control and drought treatments) that were in flushing phase 5 (leaf unfolding but not yet flattened, small), 6 (leaves still relatively small but with flattened blades, blade edges bent downwards, withered, lighter green or reddish), and 7 (leaves appear completely developed, larger but still more tenderly structured (thinner) than fully developed leaves and lighter green or reddish) at the time of the frost event (on 21st April 2017).

Because the frost-injured plants were those that had entered flushing phases 5, 6, and 7 on April 21st, we analysed the proportions of these plants from the studied provenances separately for the control and DT plots. These results are presented in Figure 6. The provenances with the largest proportion of frost-injured plants in the control plot (see Figure 4) were also those with the largest proportion of plants that had entered more advanced flushing phases, and vice versa (compare Figures 4 and 6).

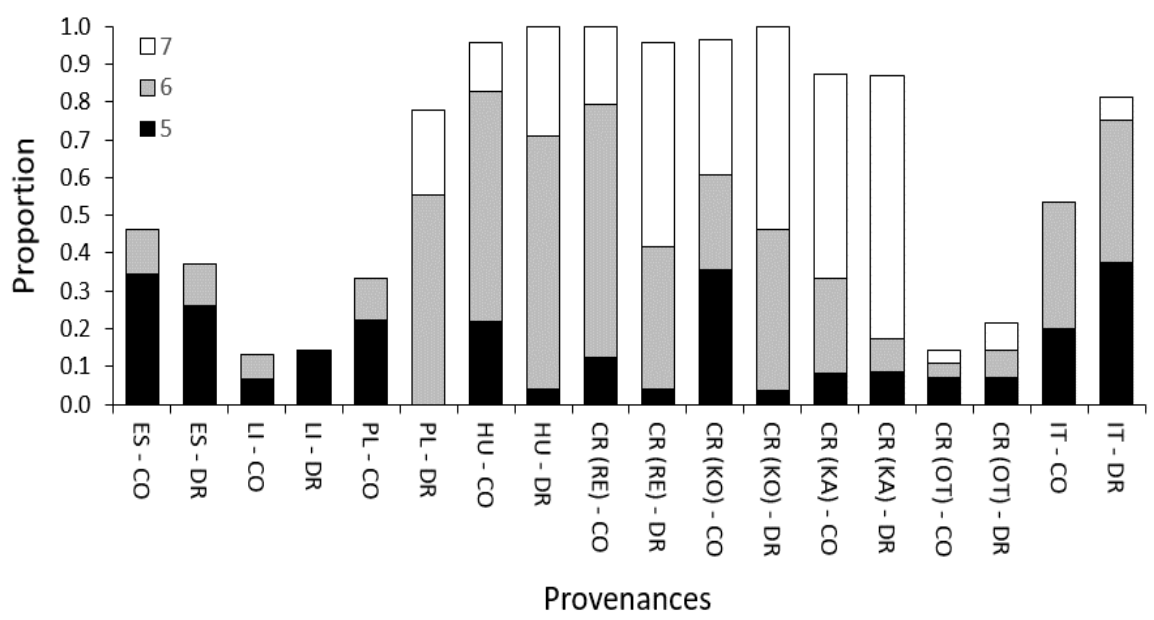

Figure 6. Proportions of plants in advanced flushing phases at the time of the frost event on 21st April 2017 by provenance and treatment: 5 (leaf unfolding but not yet flattened, small), 6 (leaves still relatively small but with flattened blades, blade edges bent downwards, withered, lighter green or reddish), and 7 (leaves completely developed, larger but still more tenderly structured (thinner) than fully developed leaves and lighter green or reddish). $\mathrm{CO}-$ control; $\mathrm{DR}-$ drought treatment. Provanance abbreviations: ES-Estonia; LI—Lithuania; PL_Poland; HU—Hungary; CR (RE)—Croatia (Repaš); CR (KO)—Croatia (Koška); CR (KA)—Croatia (Karlovac); CR (OT)—Croatia (Otok); IT—Italy. 
Additionally, the increase in frost susceptibility in the DT plot may be explained by more advanced (i.e., earlier) flushing of plants in that plot. For example, the proportion of frost-injured plants increased by $>50 \%$ in the DT plot for provenances PL (from 0\% to 78\%), HU (from 39\% to 96\%), and CR (KO) (from $43 \%$ to 96\%) (Figure 4). The same provenances exhibited the greatest shifts towards more advanced flushing on April 21st (Figure 6).

These results led to the question of why all plants that had reached flushing phase 6 (FP6) suffered frost injuries in the DT plot while only 44\% of the FP6 plants were damaged in the control plot. Thus, we tested for significant differences in the mean bud burst date between control plants not showing frost injury symptoms and drought-treated plants as well as between frost-injured control plants and drought-treated plants. These results are shown in Table 2.

Table 2. Student's $t$-test comparing the mean bud burst date between the two groups of control plants (injured or uninjured) and DT plants (all frost injured).

\begin{tabular}{cccc}
\hline $\begin{array}{c}\text { Groups of Plants which were in } \\
\text { FP } 6 \text { * } \begin{array}{c}\text { on April 21st regarding the } \\
\text { Plots and Frost Injuries }\end{array}\end{array}$ & Number of Plants & $\begin{array}{c}\text { Mean Day of the Bud } \\
\text { Burst }( \pm \text { Standard } \\
\text { Deviation) }\end{array}$ & $\begin{array}{c}\text { Difference from the } \\
\text { Group Number 2 } \\
\boldsymbol{t} \text {-Value }(\boldsymbol{p})\end{array}$ \\
\hline $\begin{array}{c}\text { 1. Uninjured control plants } \\
\text { 2. Plants in the DT plot (they were }\end{array}$ & 30 & $96.91 \pm 1,70$ & $2.898(0.0026)$ \\
$\quad \begin{array}{l}\text { all injured by the frost) } \\
\text { 3. Injured control plants }\end{array}$ & 55 & $95.77 \pm 1.80$ & \\
\hline
\end{tabular}

${ }^{*}$ flushing phase 6 . DT $=$ drought treatment.

Therefore, we compared two groups of control plants with drought-treated plants. Student's $t$-test showed that uninjured control plants had started flushing significantly later, but injured control plants had not. Although all these plants were recorded as being in flushing phase 6 on April 21st, these results (Table 2) indicate that plants in the DT plot were at a more advanced flushing state similar to that of the damaged control plants.

\section{Discussion}

\subsection{Leaf Phenology}

In our study, pedunculate oak plants that were experimentally exposed to drought exhibited delayed bud burst in the subsequent spring (Figure 2). However, after the second drought treatment, the mean bud burst date of the plants was advanced (Figure 2). This discrepancy (i.e., opposite shifts in bud burst induced by water stress) was also revealed in other studies. For example, Mijnsbrugge et al. [30] reported delayed bud burst of oak exposed to drought and Kuster et al. [28] and Spieß et al. [26] reported advanced bud burst of oak exposed to drought stress in previous years. Thus, based on our results as well as those from the above-mentioned studies, drought stress has a carry-over effect on oak flushing phenology, which causes it to shift. This effect of water stress on flushing phenology was also recorded in Fagus crenata Blume [29]. Plant environmental responses are epigenetically regulated. Various environmental signals and stresses can induce epigenetic modifications, thereby creating a flexible "memory" system for short or prolonged periods of time [35]. Changes in epigenetic marks in trees are accompanied by morphological and physiological changes in various processes such as ageing, organ maturation, and bud set or burst [36-38]. Therefore, drought stress may have triggered an epigenetic response ("memory") resulting in the observed carry-over effect on bud burst date in the oaks from the studied provenances. Why bud burst shifts may occur in opposite directions (i.e., towards an earlier or a later date) is an open question. There may be more than one molecular mechanism behind this epigenetic "memory" phenomenon. The complexity of signalling events associated with sensing drought stress in plants is well known (e.g., see [39]). Various chemical signals (e.g., reactive oxygen species, calcium, and plant hormones) participate in the induction of stress tolerance via transduction cascades and the activation of genomic re-programming [40]. For example, abscisic acid (ABA) plays an important role in epigenetic processes 
such as in ABA-mediated responses to abiotic stress (see [41]). Therefore, the complexity of drought sensing and signalling pathways likely results in different epigenetic modifications and therefore phenotypic changes such as opposite shifts in bud burst date. The different time spans over which plants sense water deficits in the vegetation period presumably cause opposite carry-over effects regarding flushing phenology. Accordingly, in the first year of the experiment, we stopped watering the plants in the DT plot on March 30th, allowing them to sense the water deficit early in the vegetation period, i.e., during or shortly after flushing. In contrast, in the second year of the experiment, the plants were deprived of water in the second half of June after they had completely developed leaves. Plants from the studied pedunculate oak provenances responded with delayed bud burst following the first drought treatment (Figure 2). Combined with advanced bud burst following the second drought treatment (Figure 2), this indicated that the hypothesis in this study was supported. Of course, the molecular mechanisms underlying the epigenetic "memory" phenomenon are still poorly understood [35]; thus, it is not clear why bud burst shifts occur in opposite directions. We can only speculate that drought in different time spans induced different sensing and signalling pathways, which resulted in the observed effects on the flushing phenology of the studied oak plants. Addressing the mechanisms underlying the observed effects of drought on flushing phenology was beyond the scope of this study.

Leaf senescence was significantly delayed by drought in plants from all provenances in both the first and second year of the experiment (Figure 3). Delayed autumn leaf senescence is a known physiological response to drought and re-watering in oaks [9,30] as well as other tree species [42]. This phenomenon has been explained as the photosynthetic and growth compensation of trees during the post-drought period of recovery. Notably, leaf senescence in the most northern provenances (i.e., Estonia and Lithuania) did not significantly differ between the DT and control plots. Plants from the northern provenances may be more sensitive to environmental signalling at the end of the growing season, which may prevent them from overextending their growing season. Vitasse et al. [43] reported a similar result in a study on clinal variation in the leaf senescence of Quercus petraea (Matt.) Liebl. from provenances along an altitudinal gradient. Additionally, Deans and Harvey [44] reported a negative correlation between leaf yellowing and latitude in sessile oak, although this correlation was not as strong as the positive correlation between budburst date and latitude. Nevertheless, natural selection in harsher (colder) habitats appears to favour genotypes that respond with more rapid growth cessation in autumn. This relationship may be why the delayed leaf senescence of plants from the northern provenances was not as significant as that of plants from the more southern provenances.

\subsection{Spring Frost Susceptibility}

Spring frost affected the trial (as well as a much wider geographic area) on the morning of April 21st, 2017. Within a few days, symptoms of necrosis were observable on plant leaves. This incident enabled us to study variation in frost susceptibility among provenances and between the treatments in the trial. There were significant differences among the studied oak provenances in terms of spring frost susceptibility. The mean proportion of injured plants was strongly related to their state of flushing development on the particular day when frost impacted the trial. Thus, differences among provenances in the proportion of frost-injured plants were caused by differences in flushing phenology. Additionally, the difference in the proportion of frost-injured plants between the control and DT plots may also be explained by differences in flushing phenology. Plants that were in more advanced flushing phases suffered leaf injury, whereas plants that had not started flushing or were in a state of less advanced flushing did not suffer damage (Figure 5). This result confirms the report by Utkina and Rubtsov [24], who found greater resilience to spring frosts of later flushing pedunculate oaks.

The most frost-susceptible plants were clearly those in flushing phase 7 (almost fully developed leaves with completely flattened blades but still tenderly structured, light green or reddish) because all but one of these plants suffered frost injuries in both the control and the DT plots. Additionally, all plants in phenological phase 6 in the DT plot were frost injured (Figure 5). Pedunculate oak do 
not appear to possess effective active molecular responses to frost; instead, avoidance is their major anti-frost "strategy". This lack of active frost responses was true at least for plants from the early flushing provenances that were exposed to the frost in 2017 and suffered leaf injury. The use of escape as an adaptive response to spring frost risks has been reported in sessile oak populations along an elevation gradient [45] as well as in various pedunculate oak populations [24,46,47]. However, the presence of a few exceptions (such as a single plant in flushing phase 7 that did not show visible symptoms of leaf injury) suggests that at least some pedunculate oak genotypes possess an efficient response to freezing at the molecular level. Such a molecular response might be due to alterations in enzymatic activity [48] and the accumulation of soluble sugars, as has already been reported for various Quercus species [49,50]; additionally, such a response might be due to the more efficient mobilization of non-structural carbohydrates (NSCs), as reviewed by Villar-Salvador et al. [51].

There was a large increase in the proportion of frost-injured plants in the DT plot (for most of the provenances), indicating an adverse impact of drought on oak frost susceptibility (Figure 4). This result raises the question of why plants in the DT plot (drought stressed) showed increased spring frost susceptibility. Based on our results, the main reason for the increased frost susceptibility of these plants was the earlier flushing caused by the drought treatment in the previous year. Drought stress in the previous year induced a clear carry-over effect, which resulted in the earlier flushing of plants from most provenances (Figure 2; year 2017). Therefore, most of the provenances in the DT plot exhibited an increased proportion of plants at more developed flushing phases on the day when the spring frost occurred. Nonetheless, it was not as obvious why all plants at flushing phase $6(100 \%)$ in the DT plot were harmed by the frost, while only $44 \%$ of plants in the same flushing phase in the control plot showed visible injuries. Drought stress may have impacted plants in the DT plot, resulting in an even more reduced efficiency of molecular responses to freezing temperatures. For example, the accumulation and re-mobilization of NSCs and nitrogen $(\mathrm{N})$ reserves play a very important role in frost resistance (see [51] and references therein). Drought stress in the current growing season may hinder re-mobilization capacity in the next growing season by decreasing seedling N and NSC content. [51]. Oaks use NSC and N reserves from storage tissues for their early spring growth before bud burst [52], and significant reductions in these reserves in spring have been reported for oaks [48]. Therefore, the higher proportion of frost-injured saplings in the DT plot may be explained in the following way: summer drought impaired the capacity to accumulate, store, and re-mobilize NSC and $\mathrm{N}$ reserves (responsible for frost resistance and vessel formation in early spring), which elevated the frost susceptibility of the saplings in the DT plot.

Another possibility was that not all plants in flushing phase 6 were in the exact same state of flushing on a particular day. Specifically, injured plants may have started flushing slightly earlier (i.e., were at a slightly more advanced flushing state) than the uninjured plants, despite all of the plants being scored as in the same flushing phase on that particular day. This explanation for the difference in the proportions of damaged phase- 6 plants between the DT and control plots is supported by the test results (Table 2). Uninjured phase-6 plants in the control plot started flushing significantly later (had an earlier bud burst date, on average), while injured phase- 6 plants did not (Table 2). Therefore, injured phase- 6 plants in the control plot and phase- 6 plants in the DT plot were at a slightly more advanced state of flushing on the day of the frost, which may have rendered them more susceptible to frost injuries. Furthermore, the flushing phenology scoring method, in which a plant was graded based on the most frequent phase, may have resulted in two plants in somewhat different states of flushing being assigned the same score. For example, if most buds indicated flushing phase 6, a plant was graded as being in phase 6; however, some newly emerging leaves may have already been in phase 7. Such plants may have sustained frost injuries on those few phase-7 leaves. Although plausible, this hypothesis should be further tested. 


\section{Conclusions}

The results of this study confirmed the previously reported effects of drought stress on pedunculate oak leaf phenology, i.e., delayed autumn leaf senescence and a carry-over effect on bud burst date. Although the effect of drought on autumn leaf senescence was unambiguous (i.e., delayed senescence), the mean bud burst dates were shifted in opposite directions in the two analyzed years. Our study supports the hypothesis that opposite shifts in bud burst dates occur due to the different times in the growing season at which plants sense water deficit signals. Accordingly, if oaks sense water deficits early in the growing season (i.e., during or shortly after flushing), then their bud burst date will be delayed in the subsequent spring. In contrast, if the oaks sense water deficit signals late in the growing season (i.e., summer drought), then their bud burst will shift towards an earlier date in the subsequent spring.

The results strongly indicated an adverse effect of drought stress on pedunculate oak spring frost susceptibility. The adverse effect was most likely caused by a shift in spring leaf phenology. In other words, summer drought stress induced a carry-over effect, resulting in earlier mean bud burst in the subsequent spring, which made plants from the majority of the studied oak provenances more susceptible to late-frost leaf injuries. Importantly, the impacts of drought on autumn leaf senescence, i.e., delayed leaf senescence, most likely increase the susceptibility of oaks to early autumn frosts.

However, plants from the latest-flushing provenances were the least sensitive to the above-mentioned adverse effects of drought on frost resistance. Therefore, these provenances may be considered valuable sources of forest reproductive material for the regeneration of oak forests made necessary by an increase in the frequency of drought and frost events.

Author Contributions: Conceptualization, K.S. and S.B.; Data curation, I.Č., A.J. and S.B.; Formal analysis, I.Č., A.J. and S.B.; Funding acquisition, S.B.; Investigation, I.Č., I.K.B. and S.B.; Methodology, K.S. and S.B.; Project administration, S.B.; Resources, I.Č. and A.J.; Supervision, S.B.; Validation, I.Č., I.K.B. and A.J.; Visualization, I.K.B. and Ž.̌̌.; Writing—original draft, I.Č. and S.B.; Writing—review \& editing, K.S., A.J. and Ž. ̌̌.

Funding: This study was fully supported by the Croatian Science Foundation under grant number IP-2014-09-4686 (Phenotypic and Epigenetic Response to Drought Stress and Adaptability of Quercus robur L. Populations along a Latitudinal Gradient).

Acknowledgments: Thank you to all those who kindly supplied acorns from their local provenances for the trial, including Dr. Moica Piazzai (Monte Rufeno Nature Reserve, Italy); Dr. Krista Takkis (Estonia); Dr. Virgilijus Baliuckas (Forest Tree Genetics and Breeding Department of the Lithuanian Research Centre for Agriculture and Forestry); Czesław Kozioł (Leśny Bank Genów Kostrzyca); Tomasz Miedzyrzecki and Bartlomiej Laski (Miękinia Forest District, Poland); Goran Perić (Forest Office Koška); staff of the Forest Office Repaš; staff of the Forest Office Karlovac and Mladen Šimunić (Forest Office Otok). The trial was maintained by employees of Nursery Production and the Division for Genetics, Forest Tree Breeding and Seed Husbandry of the Croatian Forest Research Institute. Many thanks to all of them. Thank you to the three anonymous reviewers for helpful comments and suggestions.

Conflicts of Interest: The authors declare no conflicts of interest.

\section{References}

1. Parry, M.L. Climate Change: Impacts, Adaptation and Vulnerability. Working Group II Contribution to the Fourth Assessment Report of the IPCC Intergovernmental Panel on Climate Change; Cambridge University Press: Cambridge, UK, 2007.

2. Lindner, M.; Maroschek, M.; Netherer, S.; Kremer, A.; Barbati, A.; Garcia-Gonzalo, J.; Seidl, R.; Delzon, S.; Corona, P.; Kolström, M.; et al. Climate change impacts, adaptive capacity, and vulnerability of European forest ecosystems. For. Ecol. Manag. 2010, 259, 698-709. [CrossRef]

3. Intergovernmental Panel on Climate Change (IPCC). Contribution of Working Groups I, II and III to the Fifth Assessment Report of the Intergovernmental Panel on Climate Change; Climate Change 2014: Synthesis Report; IPCC: Geneva, Switzerland, 2014.

4. Bréda, N.; Huc, R.; Granier, A.; Dreyer, E. Temperate forest trees and stands under severe drought: A review of ecophysiological responses, adaptation processes and long-term consequences. Ann. For. Sci. 2006, 63, 625-644. [CrossRef] 
5. Kreyling, J.; Stahlmann, R.; Beierkuhnlein, C. Spatial variation in leaf damage of forest trees after the extreme spring frost event in May 2011. Allgemeine Forst und Jagdzeitung 2012, 183, 15-22.

6. Ducousso, A.; Bordacs, S. EUFORGEN Technical Guidelines for genetic conservation and use for pedunculate and sessile oaks (Quercus robur and Q petraea). Available online: http:/ / www.euforgen.org/publications / publication/iquercus-roburi-and-iquercus-petraeai-technical-guidelines-for-genetic-conservation-and/ (accessed on 15 November 2018).

7. Árvai, M.; Morgós, A.; Kern, Z. Growth-climate relations and the enhancement of drought signals in pedunculate oak (Quercus robur L.) tree-ring chronology in Eastern Hungary. iForest 2018, 11, 267-274. [CrossRef]

8. Kremer, A. Evolutionary responses of European oaks to climate change. Irish For. 2010, 67, 53-66.

9. Van der Mijnsbrugge, K.; Turcsán, A.; Maes, J.; Duchêne, N.; Meeus, S.; Van der Aa, B.; Steppe, K.; Steenackers, M. Taxon-Independent and Taxon-Dependent Responses to Drought in Seedlings from Quercus robur L., Q. petraea (Matt.) Liebl. and Their Morphological Intermediates. Forests 2017, 8, 407. [CrossRef]

10. Leuschner, C.; Backes, K.; Hertel, D.; Schipka, F.; Schmitt, U.; Terborg, O.; Runge, M. Drought responses at leaf, stem and fine root levels of competitive Fagus sylvatica L. and Quercus petraea (Matt.) Liebl. trees in dry and wet years. For. Ecol. Manag. 2001, 149, 33-46. [CrossRef]

11. Kubiske, M.E.; Abrams, M.D. Stomatal and nonstomatal limitations of photosynthesis in 19 temperate tree species on contrasting sites during wet and dry years. Plant Cell Environ. 1993, 16, 1123-1129. [CrossRef]

12. Galle, A.; Haldimann, P.; Feller, U. Photosynthetic performance and water relations in young pubescent oak (Quercus pubescens) trees during drought stress and recovery. New Phytol. 2007, 174, 799-810. [CrossRef]

13. Kuster, T.M.; Arend, M.; Bleuler, P.; Gunthardt-Goerg, M.S.; Schulin, R. Water regime and growth of young oak stands subjected to air-warming and drought on two different forest soils in a model ecosystem experiment. Plant Biol. 2013, 15, 138-147. [CrossRef]

14. Kuster, T.M.; Arend, M.; Gunthardt-Goerg, M.S.; Schulin, R. Root growth of different oak provenances in two soils under drought stress and air warming conditions. Plant Soil 2013, 369, 61-71. [CrossRef]

15. Turcsán, A.; Steppe, K.; Sárközi, E.; Erdélyi, É.; Missoorten, M.; Mees, G.; Mijnsbrugge, K.V. Early Summer Drought Stress during the First Growing Year Stimulates Extra Shoot Growth in Oak Seedlings (Quercus petraea). Front. Plant Sci. 2016, 7, 193. [CrossRef] [PubMed]

16. Bruschi, P. Geographical variation in morphology of Quercus petraea (Matt.) Liebl. as related to drought stress. Plant Biosyst. 2010, 144, 298-307. [CrossRef]

17. Jensen, J.; Hansen, J. Genetic variation in responses to different soil water treatments in Quercus robur L. Scand. J. For. Res. 2010, 25, 400-411. [CrossRef]

18. Arend, M.; Kuster, T.; Günthardt-Goerg, M.S.; Dobbertin, M. Provenance-specific growth responses to drought and air warming in three European oak species (Quercus robur, Q. petraea and Q. pubescens). Tree Physiol. 2011, 31, 287-297. [CrossRef] [PubMed]

19. Broadmeadow, M.S.J.; Jackson, S.B. Growth responses of Quercus petraea, Fraxinus excelsior and Pinus sylvestris to elevated carbon dioxide, ozone and water supply. New Phytol. 2000, 146, 437-451. [CrossRef]

20. Thomas, F.M.; Gausling, T. Morphological and physiological responses of oak seedlings (Quercus petraea and Q. robur) to moderate drought. Ann. For. Sci. 2000, 57, 325-333. [CrossRef]

21. Quero, J.L.; Villar, R.; Marañón, T.; Zamora, R. Interactions of drought and shade effects on seedlings of four Quercus species: Physiological and structural leaf responses. New Phytol. 2006, 170, 819-834. [CrossRef]

22. Selig, M.; Bohne, H. Late frost reactions of different populations of Quercus robur L. and Tilia cordata Mill. in Germany. Eur. J. Hortic. Sci. 2016, 81, 157-164. [CrossRef]

23. Alberto, F.; Bouffier, L.; Louvet, J.-M.; Lamy, J.-B.; Delzon, S.; Kremer, A. Adaptive responses for seed and leaf phenology in natural populations of sessile oak along an altitudinal gradient. J. Evolut. Biol. 2011, 24, 1442-1454. [CrossRef]

24. Utkina, I.A.; Rubtsov, V.V. Studies of Phenological forms of Pedunculate Oak. Contemp. Probl. Ecol. 2017, 10, 804-811. [CrossRef]

25. Bertin, R.I. Plant phenology and distribution in relation to recent climate change. J. Torrey Bot. Soc. 2008, 135, 126-146. [CrossRef]

26. Spieß, N.; Oufir, M.; Matušíková, I.; Stierschneider, M.; Kopecky, D.; Homolka, A.; Burg, K.; Fluch, S.; Hausman, J.F.; Wilhelm, E. Ecophysiological and transcriptomic responses of oak (Quercus robur) to long-term drought exposure and rewatering. Environ. Exp. Bot. 2012, 77, 117-126. [CrossRef] 
27. Pflug, E.E.; Siegwolf, R.; Buchmann, N.; Dobbertin, M.; Kuster, T.M.; Gunthardt-Goerg, M.S.; Arend, M. Growth cessation uncouples isotopic signals in leaves and tree rings of drought-exposed oak trees. Tree Physiol. 2015, 35, 1095-1105. [CrossRef] [PubMed]

28. Kuster, T.; Dobbertin, M.; Günthardt-Goerg, M.; Schaub, M.; Arend, M. A Phenological Timetable of Oak Growth under Experimental Drought and Air Warming. PLoS ONE 2014, 9, e89724. [CrossRef]

29. Yonekura, T.; Yoshidome, M.; Watanabe, M.; Honda, Y.; Ogiwara, I.; Izuta, T. Carry-over effects of ozone and water stress on leaf phenological characteristics and bud frost hardiness of Fagus crenata seedlings. Trees 2004, 18, 581-588. [CrossRef]

30. Mijnsbrugge, K.; Turcsán, A.; Maes, J.; Duchêne, N.; Meeus, S.; Steppe, K.; Steenackers, M. Repeated Summer Drought and Re-watering during the First Growing Year of Oak (Quercus petraea) Delay Autumn Senescence and Bud Burst in the Following Spring. Front. Plant Sci. 2016, 7, 419. [CrossRef]

31. Andivia, E.; Fernández, M.; Vázquez-Piqué, J.; Alejano, R. Two provenances of Quercus ilex ssp. ballota (Desf) Samp. nursery seedlings have different response to frost tolerance and autumn fertilization. Eur. J. For. Res. 2012, 131, 1091-1101. [CrossRef]

32. Thomas, F.; Ahlers, U. Effects of excess nitrogen on frost hardiness and freezing injury of above-ground tissue in young oaks (Quercus petraea and Q. robur). New Phytol. 1999, 144, 73-83. [CrossRef]

33. Sabin, T.E.; Stafford, S.G. Assessing the Need for Transformation of Response Variables; Forest Research Laboratory, Oregon State University: Corvallis, OR, USA, 1990; p. 31

34. Littell, R.C.; Milliken, G.A.; Stroup, W.W.; Wolfinger, R.D. SAS System for Mixed Models, 6th ed.; SAS Institute: Cary, NC, USA, 2006.

35. Bräutigam, K.; Vining, K.; Lafon-Placette, C.; Fossdal, C.; Mirouze, M.; Marcos, J.; Fluch, S.; Fraga, M.F.; Guevara, M.Á.; Abarca, D.; et al. Epigenetic regulation of adaptive responses of forest tree species to the environment. Ecol. Evol. 2013, 3, 399-415. [CrossRef]

36. Fraga, M.F.; Rodriguez, R.; Canal, M.J. Genomic DNA methylation-demethylation during aging and reinvigoration of Pinus radiata. Tree Physiol. 2002, 22, 813-816. [CrossRef] [PubMed]

37. Santamaria, M.E.; Hasbun, R.; Valera, M.J. Acetylated H4 histone and genomic DNA methylation patterns during bud set and bud burst in Castanea sativa. J. Plant Physiol. 2009, 166, 1360-1369. [CrossRef]

38. Valledor, L.; Hasbún, R.; Meijón, M. Involvement of DNA methylation in tree development and micropropagation. Plant Cell Tissue Organ Culture 2007, 91, 75-86. [CrossRef]

39. Chaves, M.; Maroco, J.; Pereira, J. Understanding plant responses to drought-From genes to the whole plant. Funct. Plant Biol. 2003, 30, 239-264. [CrossRef]

40. Farooq, M.; Wahid, A.; Kobayashi, N.; Fujita, D. Plant drought stress: Effects, mechanisms and management. Agron. Sustain. Dev. 2009, 29, 185-212. [CrossRef]

41. Chinnusamy, V.; Gong, Z.; Zhu, J. Abscisic Acid-mediated Epigenetic Processes in Plant Development and Stress Responses. J. Integr. Plant Biol. 2008, 50, 1187-1195. [CrossRef] [PubMed]

42. Arend, M.; Sever, K.; Pflug, E.; Gessler, A.; Schaub, M. Seasonal photosynthetic response of European beech to severe summer drought: Limitation, recovery and post-drought stimulation. Agric. For. Meteorol. 2016, 220, 83-89. [CrossRef]

43. Vitasse, Y.; Delzon, S.; Bresson, C.C.; Michalet, R.; Kremer, A. Altitudinal differentiation in growth and phenology among populations of temperate-zone tree species growing in a common garden. Can. J. For. Res. 2009, 39, 1259-1269. [CrossRef]

44. Deans, J.D.; Harvey, F.J. Phenologies of sixteen European provenances of sessile oak growing in Scotland. Forestry 1995, 68, 265-274. [CrossRef]

45. Dantec, C.; Ducasse, H.; Capdevielle, X.; Fabreguettes, O.; Delzon, S.; Desprez-Loustau, M. Escape of spring frost and disease through phenological variations in oak populations along elevation gradients. J. Ecol. 2015, 103, 1044-1056. [CrossRef]

46. Puchałka, R.; Koprowski, M.; Przybylak, J.; Przybylak, R.; Dabrowski, H.P. Did the late spring frost in 2007 and 2011 affect tree-ring width and earlywood vessel size in Pedunculate oak (Quercus robur) in northern Poland? Int. J. Biometeorol. 2016, 60, 1143-1150. [CrossRef] [PubMed]

47. Puchałka, R.; Koprowski, M.; Gričar, J.; Przybylak, R. Does tree-ring formation follow leaf phenology in Pedunculate oak (Quercus robur L.)? Eur. J. For. Res. 2017, 136, 259-268. [CrossRef]

48. Ebermann, R.; Korori, S.A.A.; Lickl, E. Temperature Dependent Alterations of Peroxidase and Amylase Isoenzymes in Quercus robur. Phyton 1991, 31, 121-128. 
49. Morin, X.; Améglio, T.; Ahas, R.; Kurz-Besson, C.; Lanta, V.; Lebourgeois, F.; Miglietta, F.; Chuine, I. Variation in cold hardiness and carbohydrate concentration from dormancy induction to bud burst among provenances of three European oak species. Tree Physiol. 2007, 27, 817-825. [CrossRef] [PubMed]

50. Holland, V.; Koller, S.; Lukas, S.; Brüggemann, W. Drought- and frost-induced accumulation of soluble carbohydrates during accelerated senescence in Quercus pubescens. Trees 2016, 30, 215-226. [CrossRef]

51. Villar-Salvador, P.; Uscola, M.; Jacobs, D. The role of stored carbohydrates and nitrogen in the growth and stress tolerance of planted forest trees. New For. 2015, 46, 813-839. [CrossRef]

52. Michelot, A.; Simard, S.; Rathgeber, C.; Dufrêne, E.; Damesin, C. Comparing the intra-annual wood formation of three European species (Fagus sylvatica, Quercus petraea and Pinus sylvestris) as related to leaf phenology and non-structural carbohydrate dynamics. Tree Physiol. 2012, 32, 1033-1045. [CrossRef] [PubMed]

C 2019 by the authors. Licensee MDPI, Basel, Switzerland. This article is an open access article distributed under the terms and conditions of the Creative Commons Attribution (CC BY) license (http:// creativecommons.org/licenses/by/4.0/). 